\title{
糖および類縁化合物の官能基变換
}

\author{
北 川 勲*吉川 雅 之*

\section{Electrochemical Modifications of Carbohydrates and Related Compounds.}

Isao KITAGAWA* and Masayuki YoshIKAWA*

\begin{abstract}
By use of electrochemical reactions, aldonic acids, alditols, and aminocyclitols have been synthesized. Electrochemical reactions have also been utilized for removal of protecting groups in various syntheses and for chemical modifications of triterpene-oligosides, nucleosides, and aminoglycoside-antibiotics. This article reviews recent topics on functional group modifications and chemical modifications and syntheses of carbohydrates and related compounds where electrochemical oxidations and reductions have been used as key-reactions.
\end{abstract}

\section{1. はじめに}

糖および類縁化合物の電極反応については, 今世紀の 初め頃から，単糖やオリゴ糖におけるアセタール基や水 酸基の酸化反応, およびアセタール基, ケタール基やラ クトン環の還元反応を中心として詳細な研究が行われ, グルコン酸カルシウム, D-マンニトール, D-ソルビトー ルなどの工業的合成法が開発された。しかし, その後, 糖質は極性が高く有機溶媒に難溶性, かつ難結晶性など の性質を有する，いわゆる “取り扱い難い化合物” の故 もあって, 電極反応を用いた糖質の合成化学的研究は, テルペノイドなどを素材とした分野に比べてその発展が 非常に遅れていた。

近年, 優れた保護基の開発および分離技術や分析機器 の進歩と相俟って, 糖質化学全般に著しい発展が見られ, 糖質の電極反応に関しても多くの興味ある知見が得られ ている。本稿では，核酸，アミノ配糖体抗生物質および トリテルペンオリゴ配糖体なども含めて, 糖質を素材と し電極反応を鍵反応とした官能基修飾，化学変換および 合成などについて最近の知見を紹介する。

\section{2. 糖質の電極酸化}

2. 1. アセタール基および水酸基の酸化アルドー ス（i）を酸性またはアルカリ性溶液中で電解するとアル ドン酸 (ii)，2-ケトアルドース(iii)，2-ケトアルドン酸

* 大阪大学薬学部生薬学教室 (

* Faculty of Pharmaceutical Sciences, Osaka University （iv）などを経て, 低分子のアルドース（v) に分解する ことが知られている

アセタール基のみを効率よく酸化するには, 水溶液中 $\mathrm{CaBr}_{2}$ (または $\mathrm{KBr}, \mathrm{NaBr}$ など) の電極酸化によって 生成する hypobromite $\left(\mathrm{BrO}^{-}\right)$により,アルドースを酸

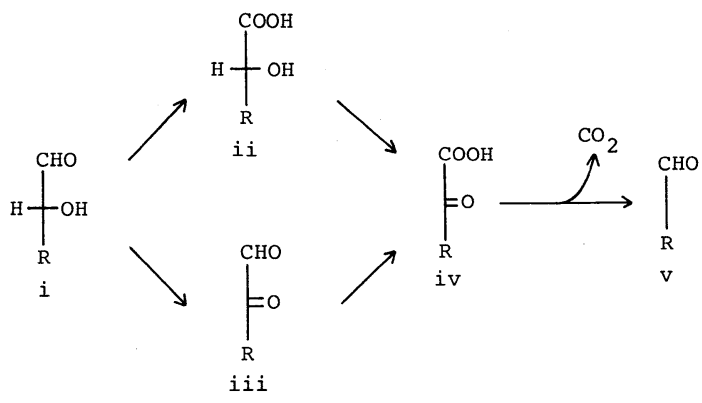

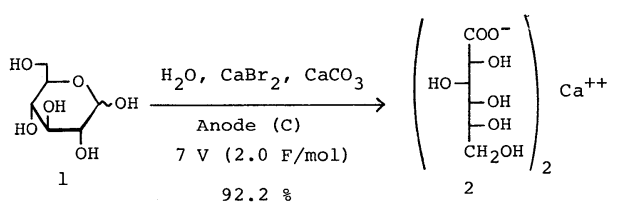

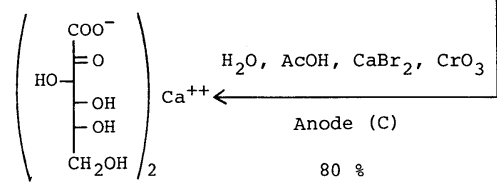

3

Fig. 1 
化してアルドン酸を合成する間接電解法が用いられてい $ろ^{1,3)}$ 。この電解法により種々のアルドン酸が合成されて いるが，本法は D-グルコース（1）からカルシウム補給 薬, グルコン酸カルシウム（2）の工業的合成法の一つ となっている4)。

また, アルドン酸の 2 位水酸基は, 酢酸水溶液中 $\mathrm{Ca}$. $\mathrm{Br}_{2}$ (または $\mathrm{NaBr}$ ) と微量 $\mathrm{CrO}_{3}$ 存在下の電解によって 選択的にケトンに酸化される

一級水酸基の酸化としては, L-ascorbic acid 合成原 料となる $2,3: 4,6$-di-O-isopropylidene-L- $x y l o-h e-$ xulosonic acid (5) の合成が詳しく検討され, 種々の電 解条件 $\left.\left(\mathrm{a}^{6)}, \mathrm{b}^{7}\right), \mathrm{c}^{1,3)}, \mathrm{d}^{8)}\right)$ が報告されている。これま でのところ, $\mathrm{Ni}(\mathrm{OH})_{2}$ 電極を用いた方法 $(\mathrm{d})$ で最も 良い結果が得られている。d の方法では, $\mathrm{Ni}(\mathrm{OH})_{2}$ 電極 から次の反応 : $\mathrm{Ni}(\mathrm{OH})_{2}+\mathrm{OH}^{-} \stackrel{-\mathrm{e}}{\longrightarrow} \mathrm{NiO}(\mathrm{OH})+\mathrm{H}_{2} \mathrm{O}$ に よって生成する $\mathrm{NiO}(\mathrm{OH})$ が水酸基を酸化すると考えら れており，4のほか種々のアルコール類の酸化に応用さ れている9)。

このほか, 電解による $\mathrm{KMnO}_{4}$ の反復再生反応を利用 した 6 からグルクロン酸誘導体（7）の合成例がある ${ }^{10}$ 。 また, 水銀陰極で生成した $\mathrm{H}_{2} \mathrm{O}_{2}$ で methyl D-glucoside （8）を酸化することによって，低収率であるが Dglucuronic acid (9) が合成されている11)。

2. 2. 脱炭酸反応による糖質の化学変換 Kolbe 反 応に代表されるように, 電極脱炭酸反応は最もよく知 られた電極反応の一つである。しかし，糖質の電極脱炭
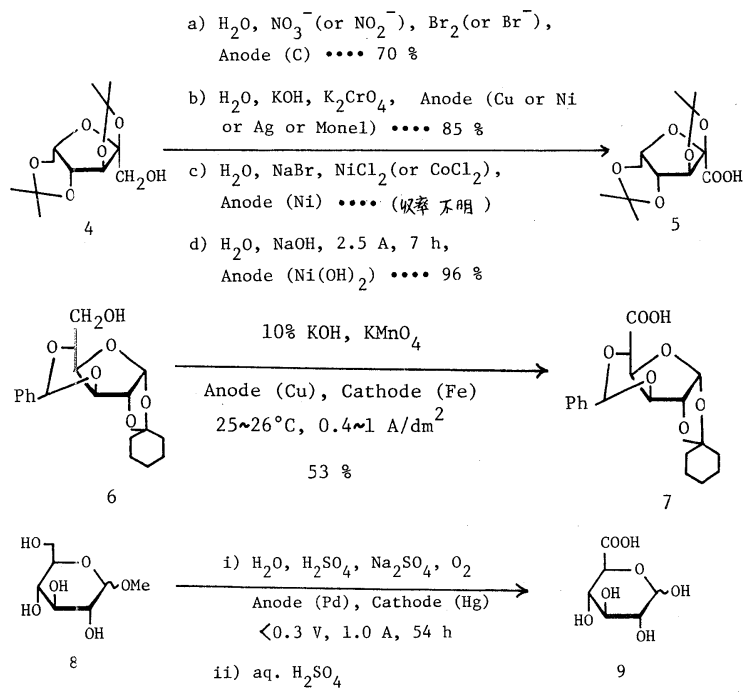

20.28

Fig. 2
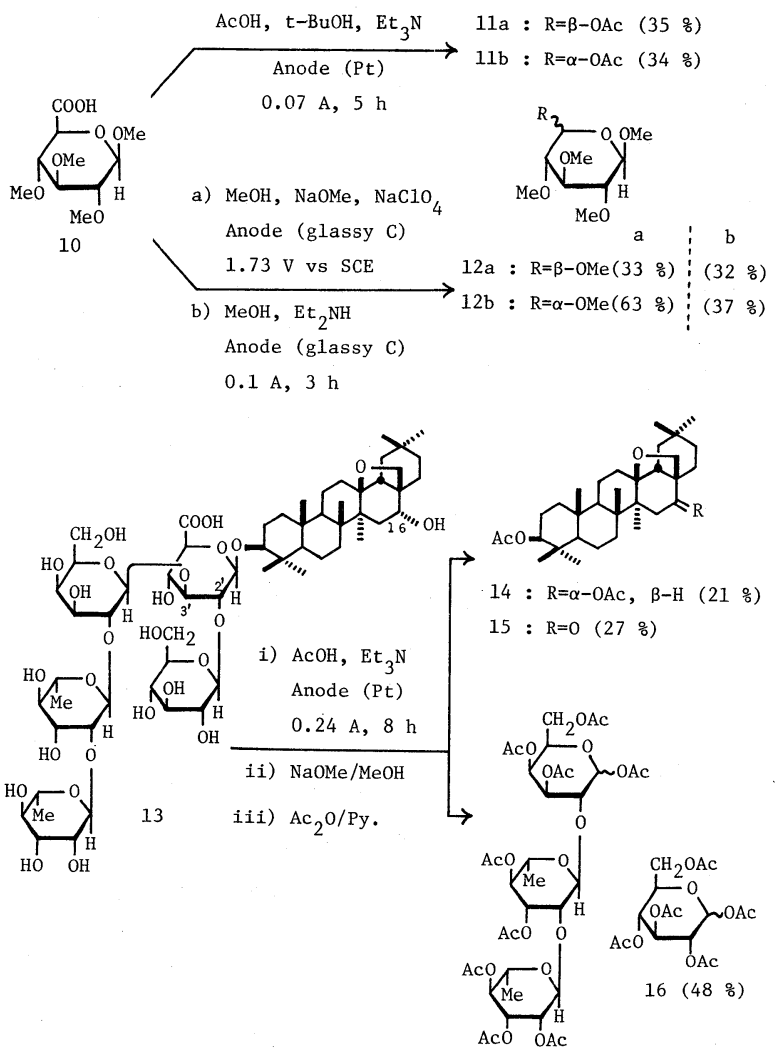

$17(35 \%)$

Fig. 3

酸反応としては, D-gluconic acid や L-arabonic acid の電解脱炭酸により，D-arabinose や L-erythrose の生 成することが定性的に知られているにすぎなかった

筆者らは，グルクロニド結合の選択的開裂法 ${ }^{12}$ の研究 過程で, グルクロニドサポニン13) のグルクロン酸部分の カルボキシル基を，四酢酸鉛により脱炭酸アセトキシル 化した後, アルカリ処理することによって, グルクロニ ド結合が選択的に開裂されることを見出した ${ }^{12)}$ 。カルボ キシル基をアセトキシル基に置換するこのような反応は, 電極酸化によっても期待されたので, グルクロン酸誘導 体（10）を用いて検討した。

10 およびそのナトリウム塩 (carboxylate 型) の酸化 電位はそれぞれ $2.10 \mathrm{~V}, 1.72 \mathrm{~V}$ (vS SCE) で, 10 Me. $\mathrm{OH}$ および $\mathrm{AcOH}$ 中定電位または定電流電解すると 11 $\mathrm{a}, 11 \mathrm{~b}, 12 \mathrm{a}, 12 \mathrm{~b}$ がそれぞれ好収率で得られた。

つぎに，この電極脱炭酸反応をグルクロニドサポニン に応用した。Sakuraso-saponin (13，ニホンサクラソウ Primula sieboldi E. Morren の根から得られる) ${ }^{13)} 10$ 
の場合と同様 $\mathrm{AcOH}$ 中定電流電解し, 得られたアセト キシル化誘導体をアルカリ処理すると, 期待通りグルク ロニド結合が選択的に開裂された生成物が得られた。分 解生成物を単離し易くするためアセチル化した後精製し， 糖部分から 16，17を得, サポゲノール部分からは真正 サポゲノール protoprimulagenin A diacetate (14)の ほかに, 副生成物として 16 位水酸基の酸化されたaegicerin acetate (15) が得られた。比較のため, protoprimulagenin A (35) を 13 の場合と同様に電解すると, aegicerin (36) (65\%) が得られたことから，本電解条 件下では，カルボキシル基の酸化的脱炭酸とともに, 副 反応として, サポゲノール部の axial 水酸基が酸化され ることが判明した ${ }^{14)}$ 。

Soyasaponin I (18, ダイズ Glycine max Merrill. の種子から得られる $)^{15)}$ を同様に電極脱炭酸一アルカリ処 理すると，オリゴ糖鎖からはアセチル化を経て 19a, 19b
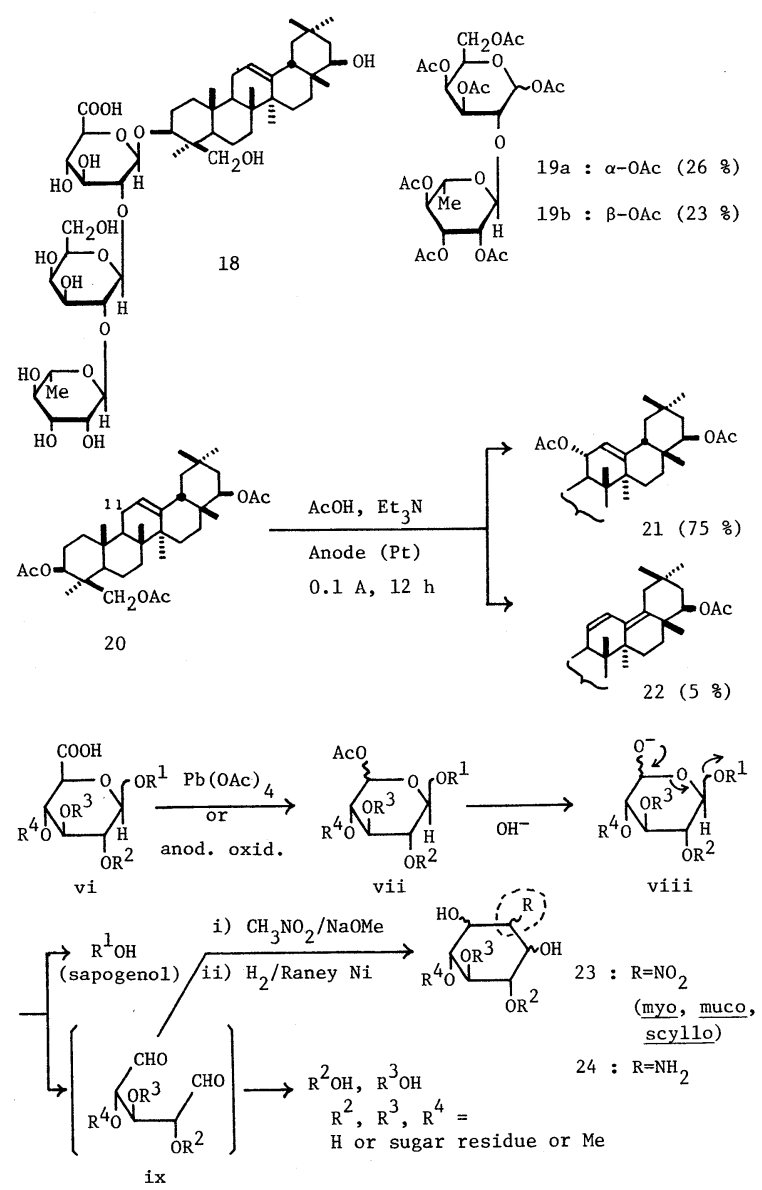

Fig. 4
が得られるが, サポゲノール部分は複雑な分解物を与え た。そこで, サポゲノール soyasapogenol B の triacetate （20）について電極反応を検討したところ，20の11位に 容易にアセトキシル基が導入され，21 と 21 から脱酢酸 して生成したと考えられるジェン化合物 22 の得られる ことが判明した ${ }^{14)}$ 。筆者らは，後に述べるように，この 電極反応をトリテルペンオリゴ配糖体の化学修飾に応用 した。

電極脱炭酸アセトキシル化反応を鍵反応としたグルク ロニド結合の開裂に, ジアルデヒド中間体(ix)を経て進 む反応経路が推定された。そこで，グルクロン酸誘導体 (10；vi : $\left.\mathrm{R}^{1}=\mathrm{R}^{2}=\mathrm{R}^{3}=\mathrm{R}^{4}=\mathrm{Me}\right)$ を用いて検討したとこ ろ,アセトキシル中間体 (11) のニトロメタンーアルカリ処 理によりニトロシクリトール (23) が得られた。この結 果, 間接的ではあるが反応経路中に拈ける ixの生成が証 明された。

このようにして, 電極脱炭酸反応を用いたグルクロニ ド結合の選択的開裂反応経路が明らかになるとともに， 脱炭酸反応とニトロメタン環化反応からなる行程が，ウ ロン酸類 (vi) からシクリトール類 (例えば 23) への化学 変換法として応用可能なことが判明した。

筆者らは，他に同様の観点から，四酢酸鉛による脱炭 酸アセトキシル化反応を鍵反応として, 糖質から種々の アミノシクリトール，分枝シクリトールおよびアミノ配 糖体抗生物質などの合成を行っている ${ }^{16)}$ 。四酢酸鉛を用 いる方法に比較して電極反応の利点は, 水酸基やアセタ ール基を保護することなく，ウロン酸類やグルクロニド サポニンを脱炭酸アセトキシル化できるところにある。

筆者らはさらに, D-glucuronic acid (25) やD-galacturonic acid (29) などのウロン酸類, D-mannose(31) から得られるウロン酸誘導体などに本反応を適用し，26, 27, 28 などのほか, 光学活性アミノシクリトール 30, 32 の合成に成功した ${ }^{17)}$ 。また, $N$-Acetyl-D-glucosamine (33) から streptamine (34) を合成し ${ }^{18)}$ ，グルクロニド サポニン, 例えば 13 から, サポゲノール 35, 36 とニトロ シクリトールオリゴ配糖体 37 を得, 37 のニトロ基の還 元, アセチル化によって, アミノシクリトールオリゴ配 糖体 38 を合成した ${ }^{17)}$ 。

このようなウロン酸誘導体の電極脱炭酸反忘は, nucleoside の化学修飾への応用が検討されている。Nucleoside から誘導される 39 を $\mathrm{MeOH}$ 中電解し 40, 41 お よび 42 が得られた。一方, $\mathrm{AcOH}$ 中での電解 $[\mathrm{AcOH}-$ THF (3:1), graphite, $\left.600 \mathrm{~mA}, 15^{\circ} \mathrm{C}\right]$ では, 低收率 であるが, $43(\alpha$-OAc $7 \%, \beta$-OAc $4 \%$ ) が得られてい る19)。 
以上の他, 電極脱炭酸反応を用いた例として， $\delta$-Dglucuronolactone (44) から，セリウム塩をメディエータ
ーとした間接電極酸化により, D-arabinose (45)が合成 されている20)。

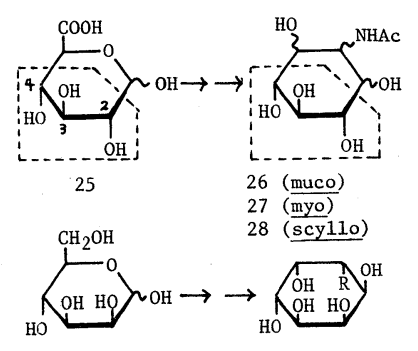

31
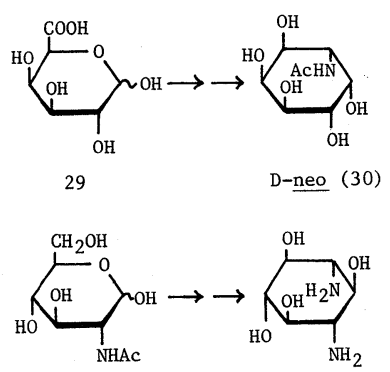

33

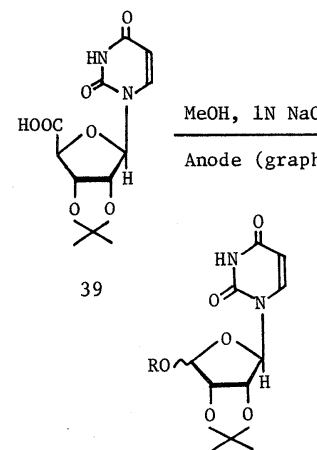

$40: \mathrm{R}=\mathrm{Me}$ (35\%)

$43: \mathrm{R}=\mathrm{Ac}$

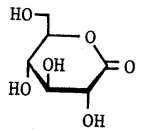

$\underset{\mathrm{MeOH}, \text { aq. } \mathrm{H}_{2} \mathrm{SO}_{4}, \mathrm{Ce}\left(\mathrm{SO}_{4}\right)_{2}}{\text { Anode }(\mathrm{Pt})}$

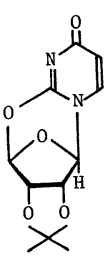

$41(20 \%)$

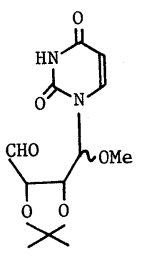

$42(11 \%)$

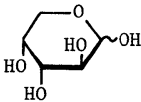

45

Fig. 6

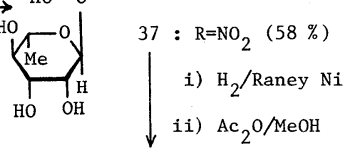

38 : $\mathrm{R}=\mathrm{NHAC}$

Fig. 5
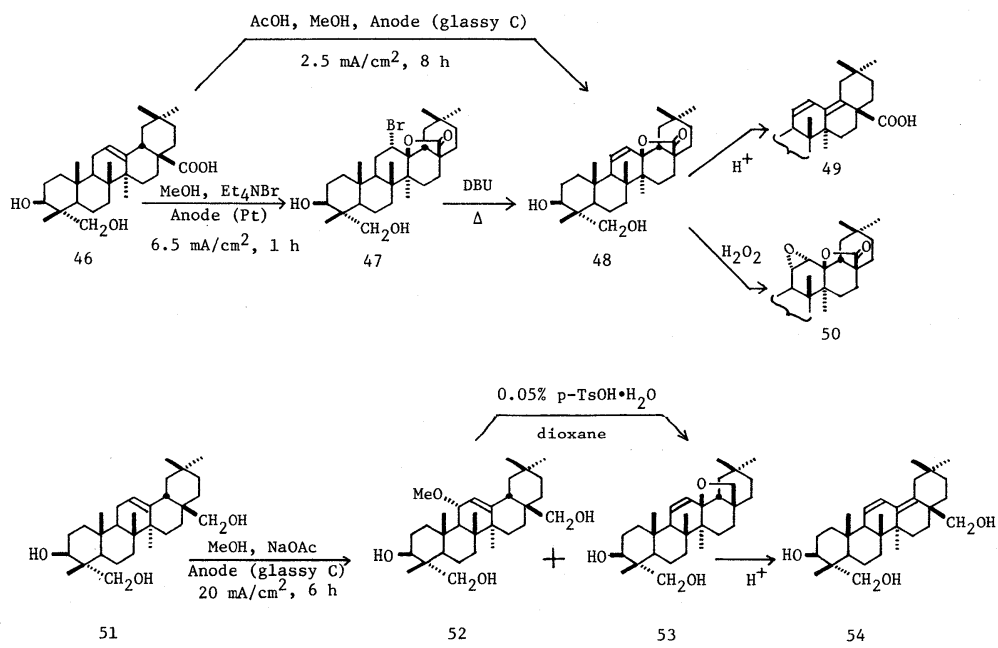

Fig. 7 
2. 3. トリテルペンオリゴ配糖体の化学修飾 グル クロニドサポニンに含まれるグルクロニド結合の選択的 開裂において，電極脱炭酸反応の有用性を上述したが， soyasapogenol B triacetate (20) で見られたように, 電極反応がオレアネン型サポゲノールの化学修飾に適用 が可能と考えられたので，数種のトリテルペンを用いて 電極反応の条件などを種々検討した。

その結果, 電極反応によってオレアネン型サポゲノー ル（例えば 46, 51）に，好収率で $\Delta^{11}-13 \beta, 28$-lactone (48), $11 \alpha, 12 \alpha$-epoxy-13 $\beta, 28$-lactone (50) および $\Delta^{11}$ -13 $\beta, 28$-oxide 構造 (53) を導入可能なことが判明した。 この電極反応条件下では水酸基の保護を必要としないの で，本反応をオレアネン型トリテルペンをサポゲノール とするオリゴ配糖体に適用すれば, オリゴ糖部分を保護す ることなく，選択的にサポゲノール部分に上記の官能基 を導入することが可能である。

$11 \alpha, 12 \alpha$-Epoxy-13 $\beta, 28$-lactone 構造をもつオレア ネン型トリテルペンのオリゴ配糖体として，フサザクラ (Euptelea polyandra Sieb. et Zucc.) の葉から得られ た抗菌性配糖体 eupteleoside（55）がある。また，漢薬， 柴胡 (Bupleurum falcatum L. の根) から得られる

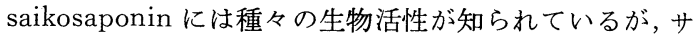
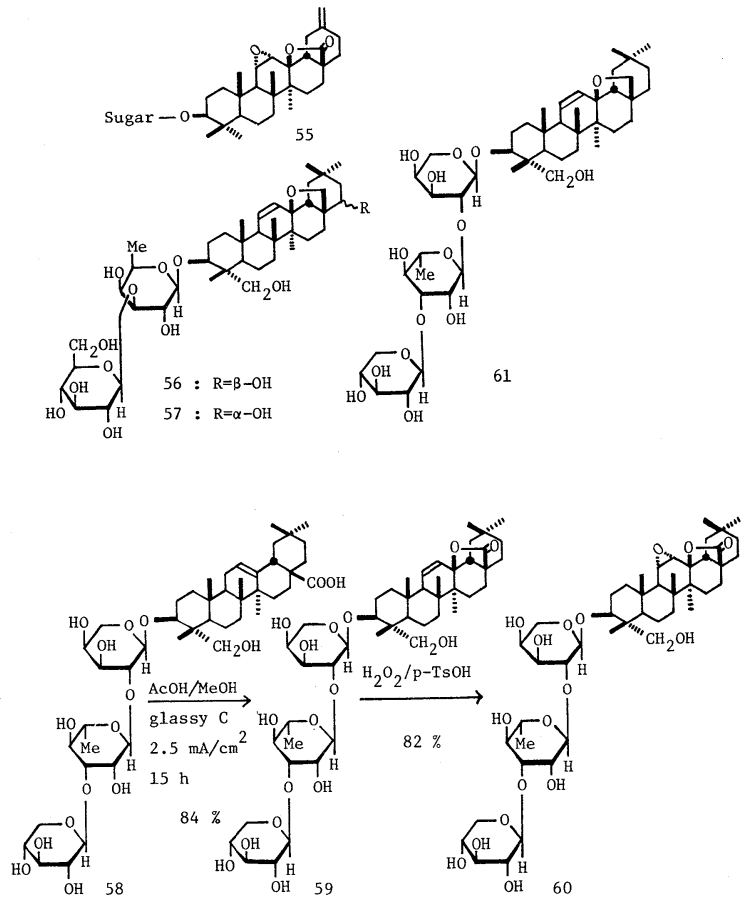

Fig. 8
ポゲール部に $4 \alpha$-hydroxymethyl 基をもち， $\Delta^{11}-13 \beta$, 28-oxide 構造を有する saikosaponin a (56) や d (57) には顕著な抗炎症活性が認められている。

筆者らは，このような官能基をもった生物活性トリテ ルペンオリゴ配糖体の構造に着目し, 延命皮 (Sapindus mukurossi Gaertn.の果皮) などに多量に含有されて いる hederagenin オリゴ配糖体 58 を素材として, 電極 反応を鍵反応とする上記官能基の導入を検討した。その 結果, $4 \alpha$-hydroxymethyl 基をもった $\Delta^{11}-13 \beta$, 28-lactone オリゴ配糖体 $59,11 \alpha, 12 \alpha$-epoxy-13 $\beta, 28$-lactone オリゴ配糖体 60，および $\Delta^{11}-13 \beta, 28$-oxide オリゴ配糖 体 61 を短行程かつ好収率で合成することに成功した ${ }^{21)}$ 。

2. 4. 保護基の除去優れた保護基の開発研究は, 糖質化学の発展に大きく寄与している。これらの保護基 の中には電極反応によって選択的に除去されるよう工夫 されている場合がある。これまでのところ, 電極酸化反 応によって除去される保護基の例は還元脱保護されるも のに比べて少なく, benzyl 基や $p$-methoxybenzyl 基が 知られているにすぎなかった ${ }^{22)}$ 。

最近, Ohtsuka らは, nucleotide の保護基として $p$ -

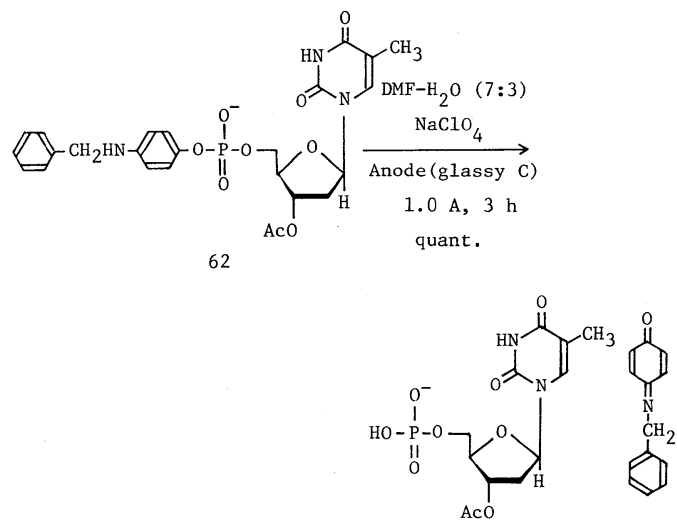

$63 \quad 64$

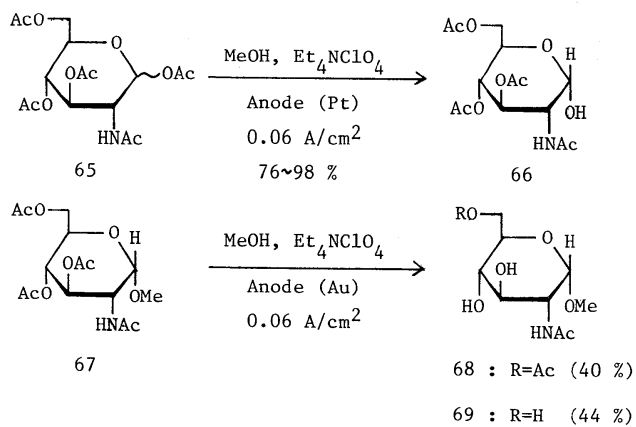

Fig. 9 
$N$-benzylaminophenyl 基, $p$ - $N$-tritylaminophenyl 基， $p$ - $N$-acetylaminophenyl 基，および $p$-methoxy phenyl 基について検討し, $p$ - $N$-benzylaminophenyl 基 が定電位電解によって容易に除去されることを明らかに している ${ }^{23)}$ 。

このほか, D-glucosamine の acetyl 化誘導体 65, 67 が $\mathrm{MeOH}$ 中の定電流電解によって脱 O-アセチル化され ることが知られている ${ }^{24)}$ 。

\section{3. 糖質の電極還元反応}

3. 1. アセタール基, ケタール基およびラクトン環の 還元 Creightonによって開発された単糖から糖アル コールへの電極変換反応は, D-mannitol, D-glucitol (70)の工業的合成法として利用されていた。その後, 電 解条件について詳細な検討が行われ, 微量副生成物の組 成も明らかにされている3,25,26)。
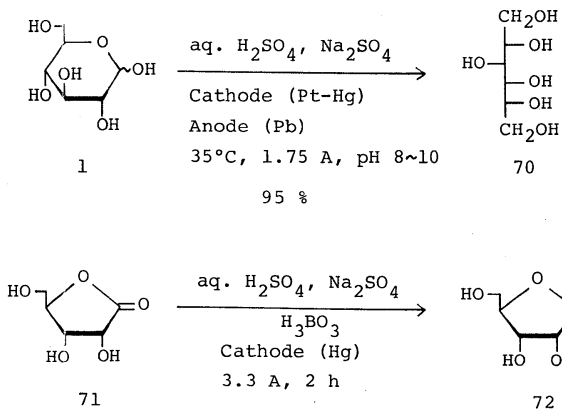

$60 \%$

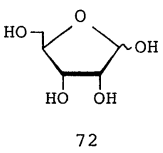

Fig. 10

また，アルドン酸の $1,4-$ アトトン (71) が電極還元に よってアルドース（72）を生成することが報告されてい $ろ^{3,25,27)}$ 。この反応は, 電解時に生成した amalgam に よって還元反応が進行すると考えられている。

3. 2. 糖質の化学修飾 Nucleoside の化学修飾に 電極還元反応を応用した例として，ヨード化誘導体 73, 74 の電解によるシクロプロパン環をもつ nucleoside 78, 79 の合成がある。しかし，77 を同条件で電解すると thymine $(80,81 \%)$ が得られ，クロル化誘導体 75, 76 の電 解では，配糖体結合が開裂される ${ }^{28)}$ 。

一方, ブロム化誘導体 $81,82,85$ の電極還元によって $2^{\prime}, 3^{\prime}$-不飽和型の nucleoside 83，84，86 が好収率で合成 されている。しかし，85を他の電解条件で還元した場合， 配糖体結合の開裂を伴い86の収率が低い29)。

このほか, $2^{\prime}, 3^{\prime}$-不飽和型の nucleoside 類 92 は, ヨ ード化誘導体 89, 90, 91 の電極還元によっても得られ ることが知られている ${ }^{30)}$ 。
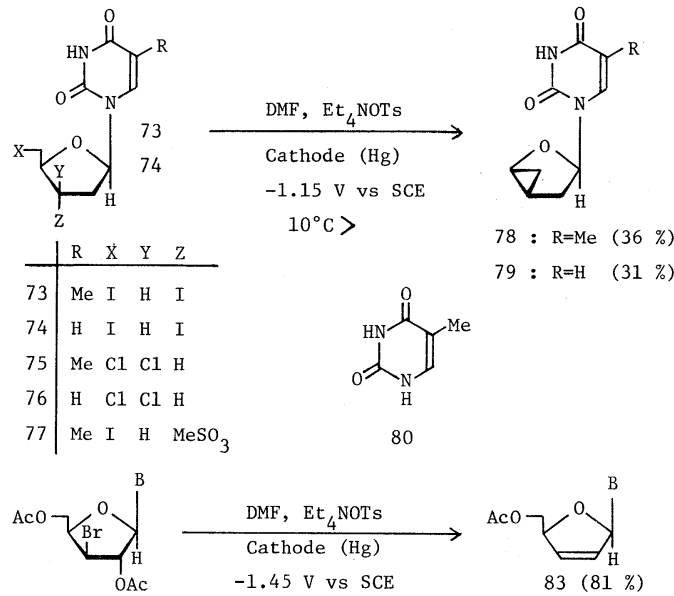

$81,82 \quad 10^{\circ} \mathrm{C}, 50 \sim 200 \mathrm{~mA}, 2 \mathrm{~h} \quad 84$ (73\%)
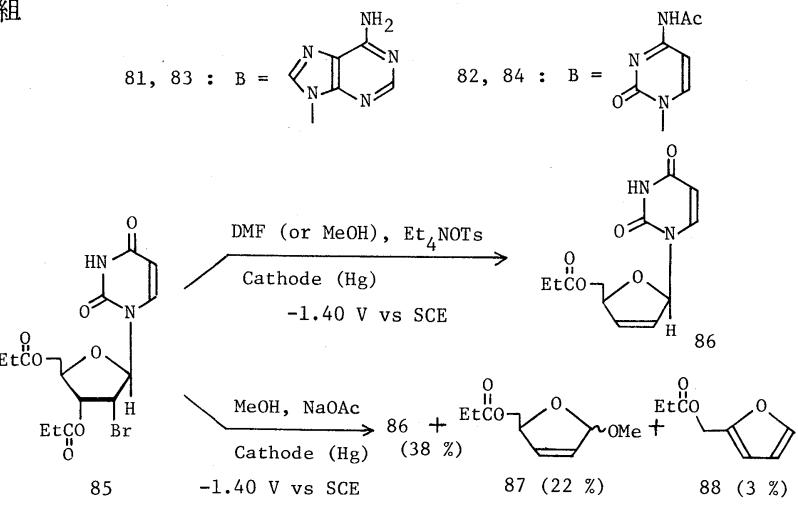

Fig. 11

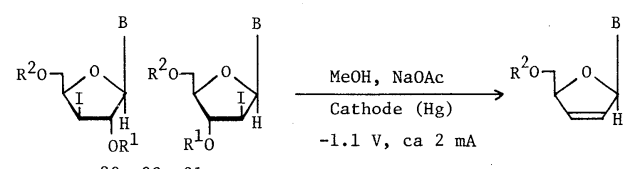

$89,90,91$

92

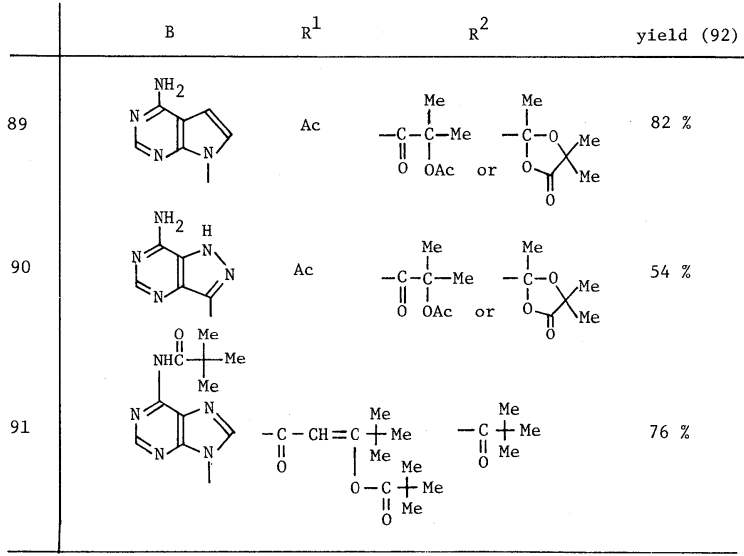

Fig. 12 


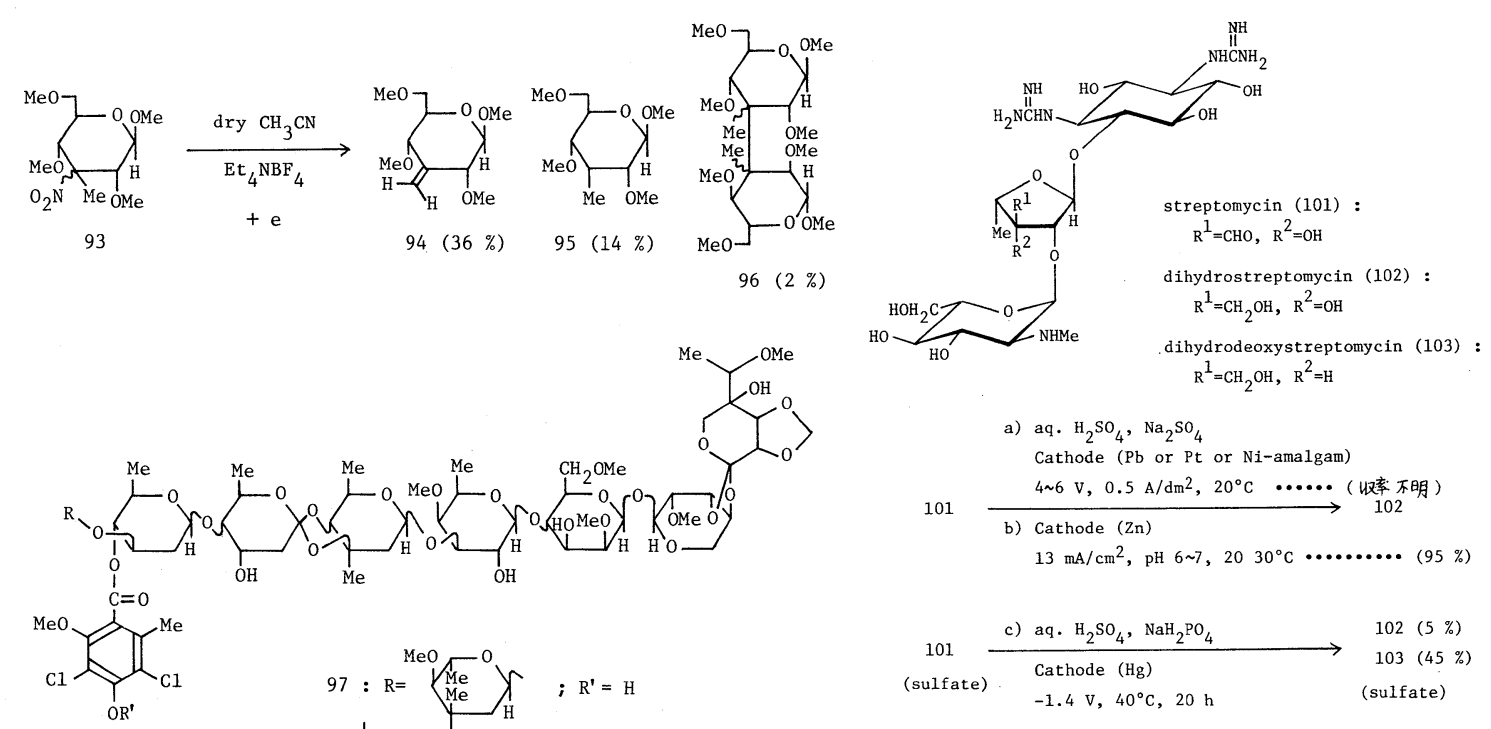

Fig. 14

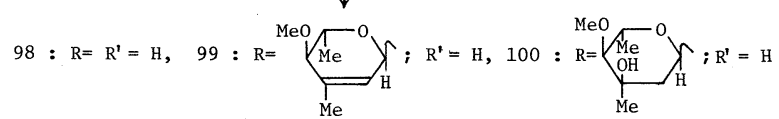

Fig. 13

Everninomicin D (97) は, Micromonospora carbonaceae から単離され, グラム陽性菌に有効なオリゴ 配糖体抗生物質で, その化学構造中にニトロ基と 2 個の オルトエステル基を有する複雑で興味深い化学構造をも つ化合物である。97の化学修飾のモデル実験として, ま ず, ニトロ糖 93 の電極反応が検討され，93 を電極還元 (条件の詳細は不明) すると 94，95，96 が得られた。 そこで, 97 を同様に電解すると everninomicin-2 (98), -3 (99)，-7 (100) が得られた。98，99，100はグラム 陽性菌に対して強い抗菌性を示し, 特に 99 は 97 に比べ て薬力学的に改良されている311。

アミノ配糖体抗生物質の化学修飾にも電極還元法が利 用されている。例えば, streptomycin (101) の電極還元 により dihydrostreptomycin (102) や dihydrodeoxy streptomycin (103) が誘導されている32)。

Igarashi らは, tobramycin (111) や kanamycin A (114)の 1-および 3-hydroxyimino 誘導体 104, 105, 108 の電極還元を検討している。

1-Hydroxyimino 誘導体 104, 105 からは，それぞれ 106, 107 を経て, 1-epi-tobramycin (112)および1-epikanamycin A (115) を，他の還元剂を用いた場合よりも 好収率で合成することに成功している。

一方, 3-hydroxyimino 誘導体 (108) を 104, 105 の

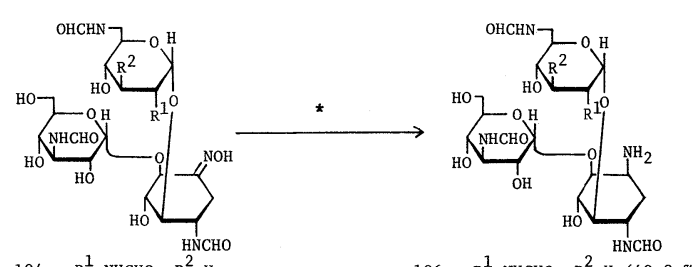

$104: \mathrm{R}^{1}=\mathrm{NHCHO}, \mathrm{R}^{2}=\mathrm{H} \quad 106: \mathrm{R}^{1}=\mathrm{NHCHO}, \mathrm{R}^{2}=\mathrm{H}(49.8 \%)$ $105: \mathrm{R}^{1}=\mathrm{R}^{2}=\mathrm{OH} \quad 107: \mathrm{R}^{1}=\mathrm{R}^{2}=\mathrm{OH}(44.5 \%)$

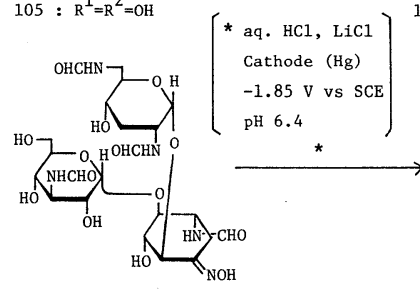

108

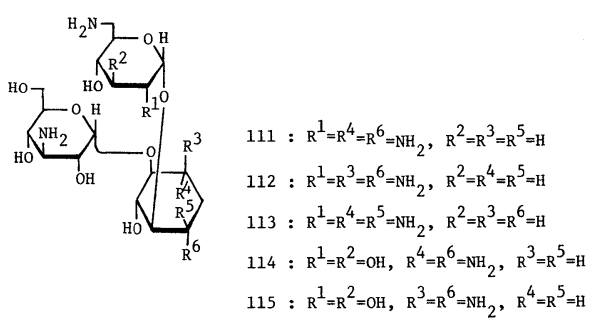

Fig. 15

場合と同条件で電解した場合には, tobramycin 型誘導 体 (110) が主生成物として得られ，3-epi-tobramycin 型誘導体 (114) の収率は低かった。 
なお，1-epiおよび 3-epi-tobramycin $(112,113)$ や 1-epi-kanamycin A (115) の抗菌性は，それぞれ tobramycin (111) や kanamycin A (114) よりも弱いことが 判明している ${ }^{33)}$ 。

\section{3. 保護基の除去 これまでのところ, 電極反応} による保護基の除去には，還元反応が用いられる場合が 多い。例えば, benzoyl 基と benzylidene基は還元電位 を変えることによって選択的に除去され，例えば，116 は 117 また 118 をえる。また, trityl 基（例えば, 119 ) も電極還元によって除去される22)。

電極還元による保護基の選択的除去を利用した nucleotide の合成は興味深い例である。120a, 120b, 120c を 電解すると選択的に $121 \mathrm{a}, 121 \mathrm{~b}, 121 \mathrm{c}$ が得られ，121a， $121 \mathrm{~b}, 121 \mathrm{c}$ と 122a，122b，122c をそれぞれ縮合させて 123a，123b，123c が合成された。また, 電解条件を変え ることによって, 122a, 122b, 122c は 124a, 124b, 124c
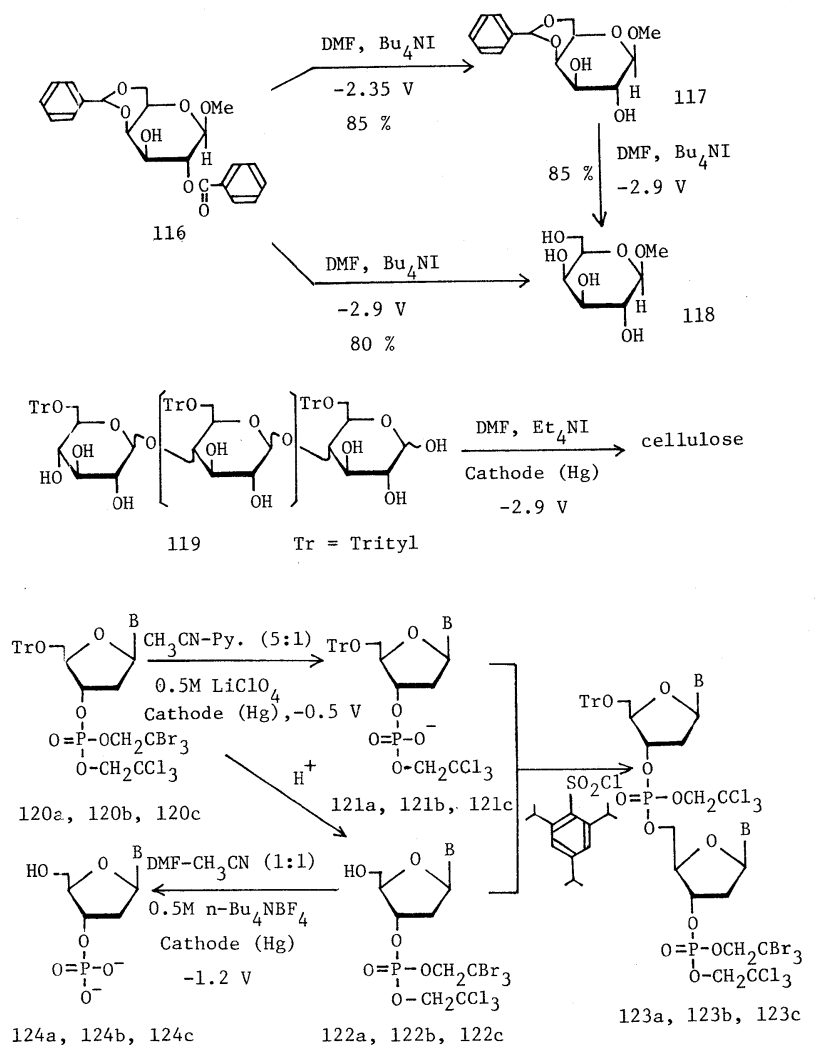

120a, 121a, 122a, 123a, 124a : B = Thyminy1

$120 \mathrm{~b}, 121 \mathrm{~b}, 122 \mathrm{~b}, 123 \mathrm{~b}, 124 \mathrm{~b}: \mathrm{B}=\mathrm{N}^{4}$-Benzoylcytosy 1

$120 \mathrm{c}, 121 \mathrm{c}, 122 \mathrm{c}, 123 \mathrm{c}, 124 \mathrm{c}: \mathrm{B}=\mathrm{N}^{6}$-Benzoyladeny 1

Fig. 16
に誘導されている。

\section{4. おわりに}

糖質を素材とした化学変換研究の観点から, 最近の研 究例を中心にまとめた。糖質の化学変換や合成における 最も重要な問題点の一つに, 有機溶媒への溶解性とも関 連して, 水酸基およびアセタール基に対する保護基の選 択がある。しかし，電極反応においては，本稿でもしば しば見られるように，反応条件を検討すれば，水酸基の 保護を必要としないで目的とする反応を進められる場合” がある。また, 電極反応の溶媒として, 水, メタノール など高極性溶媒の使用が可能など, 糖質に適用するには 好都合なことも多い。

今後, 糖質化学の進展に, 電極反応がさらに大きく寄 与することが期待される。

（昭和 60 年 3 月 19 日受理）

\section{文献}

1) N. L. Weinberg, H. R. Weinberg, Chem. Rev., 68, 449 (1968)

2) G. W. Hay, F. Smith, Can. J. Chem., 47, 417 (1969)

3) M. Fedoronko, Advan. Carbohyd. Chem. Biochem., 29, 107 (1974)

4a）水口 純, 薬誌, 70, 613 (1950)

b) 伊藤 黋, 有合化, 11, 252 (1953)

5) R. Pasternack, P. P. Regna, USP, 2222155 ; Chem. Abstr., 35, 1326 (1941)

6) J. E. Slager, N. D. Dawson, USP, 2960452 ; Chem. Abstr., 55, $12312 \mathrm{~g}$ (1961)

7) A. Verheyden, USP, 2559033 ; Chem. Abstr., 45, 8926c (1951)

8) G. Vertes, G. Horanyi, F. Nagy, Tetrahedron, 28, 37 (1972)

9) J. Kaulen, H. J. Schafer, Synthesis, 1979, 513

10）田鹿義雄, 倉成雅夫, 薬誌, 72, 1045 (1952)

11) R. A. Leutgoeb, H. Heinrich, J. Am. Chem. Soc., 61, 870 (1939)

12a) I. Kitagawa, M. Yoshikawa, Heterocycles, 8, 783 (1977)

b) 北川 勲, 化学の領域増刊 125 号「天然物化学 '80 A」, pp 45-61 (1980)

c) I. Kitagawa, "Isopentenoids in Plants, Biochemistry and Function", edited by W.D. Nes, G. Fuller, L. S. Tsai, Marcel Dekker, Inc., New York, Basel, 1984, p. 209

13) I. Kitagawa, M. Yoshikawa, K. Kobayashi, Y. Imakura, K. S. Im, Y. Ikenishi, Chem. Pharm. Bull., 28, 296 (1980)

14) I. Kitagawa, T. Kamigauchi, H. Ohmori, M. Yoshikawa, ibid., 28, 3078 (1980) 
15) I. Kitagawa, M. Yoshikawa, H. K. Wang, M. Saito, V. Tosirisuk, T. Fujiwara, K. Tomita, ibid., 30, 2294 (1982)

16a) I. Kitagawa, M. Yoshikawa, A. Kadota, ibid., 26, 484 (1978)

b) I. Kitagawa, A. Kadota, M. Yoshikawa, ibid., 26, 3825 (1978)

c) M. Yoshikawa, Y. Ikeda, H. Kayakiri, I. Kitagawa, Heterocycles, 17, 209 (1982)

d) M. Yoshikawa, Y. Ikeda, H. Kayakiri, K. Takenaka, I. Kitagawa, Tetrahedron Lett., 23 , 4717 (1982)

e) M. Yoshikawa, Y. Ikeda, K. Takenaka, M. Torihara, I. Kitagawa, Chem. Lett., 1984, 2097

f) I. Kitagawa, T. Kamigauchi, Y. Ikeda, M. Yoshikawa, Chem. Pharm. Bull., 32, 4858 (1984)

17a) I. Kitagawa, T. Kamigauchi, K. Shirakawa, Y. Ikeda, H. Ohmori, M. Yoshikawa, Heterocycles, 15, 349 (1981)

b) I. Kitagawa, M. Yoshikawa, T. Kamigauchi, K. Shirakawa, Y. Ikeda, Chem. Pharm. Bull., 29, 2571 (1981)

18) M. Yoshikawa, T. Kamigauchi, Y. Ikeda, I. Kitagawa, ibid., 29, 2582 (1981)

19) K. Kondo, I. Inoue, J. Org. Chem., 44, 4713 (1979)

20）中村好男, 日化誌, 103，1727（1982）

21) M. Yoshikawa, H. K. Wang, V. Tosirisuk, I. Kitagawa, Chem. Pharm. Bull., 30, 3057 (1982)

22) V. G. Mairanovsky, Angew. Chem. Int. Ed. Engl., 15, 281 (1976)
23) E. Ohtsuka, T. Miyake, M. Ikehara, A. Matsumoto, H. Ohmori, Chem. Pharm. Bull., 27, 2242 (1979)

24) T. Imagawa, Y. Nakashima, M. Kawanisi, Chem. Lett., 1980, 1609

25) F. D. Popp, H. P. Schultz, Chem. Rev., 62, 19 (1962)

26) V.Craiu, P.Anghel, M.Burnei, Rev. Chim., 9, 447 (1958) ; Chem. Abstr., 55, 20973 (1961)

27) 佐藤徹雄, 日化誌, 71, 194 (1950)

28) T. Adachi, T. Iwasaki, M. Miyoshi, I. Inoue, J. Chem.Soc., Chem. Commun., 1977, 248

29) T. Adachi, T. Iwasaki, I. Inoue, M. Miyoshi, J. Org. Chem., 44, 1404 (1979)

30) R. Mengel, J. Seifert, Tetrahedron Lett., 1977, 4203

31) A. K. Ganguly, P. Kabasakalian, J. Morton, O. Sarre, A. Westcott, S. Kalliney, P. Mangiaracina, A. Papaphilippou, J. Chem. Soc., Chem. Commun., 1980, 56

32a) T. Ueda, I. Nakata, S. Ito, Chem. Pharm. Bull., 1, 322 (1953)

b) N. E. Khomutov, T. P. Fadeeva, V. V. Skornyakov, A. M. Zisserman, N. M. Mishina, Med. Prom. SSSR, 18, 20 (1964); Chem. Abstr., 60, $15682 \mathrm{f}$ (1964)

c) K. Tsuji, Agric. Biol. Chem., 25, 432 (1961)

33) K. Igarashi, T. Sugawara, T. Honma, Y. Tada, H. Miyazaki, H. Nagata, M. Mayama, T. Kubota, Carbohydr. Res., 109, 73 (1982)

34) J. Engels, Angew. Chem. Int. Ed. Engl., 18, 148 (1979) 